\title{
THE INFLUENCE OF WEATHER CONDITIONS OF EASTERN POLAND ON SWEET CORN YIELDS AND LENGTH OF GROWING SEASON
}

\author{
Robert Rosa' ${ }^{1}$ Edyta Kosterna-Kelle' ${ }^{1}$ Jolanta Franczuk' ${ }^{1}$ Anna Zaniewicz-Bajkowska' ${ }^{1}$ \\ 1 Siedlce University of Natural Sciences and Humanities, Konarskiego 2 Str., 08-110 Siedlce, Poland, e-mail: \\ robert.rosa@uph.edu.pl
}

Received: 2016.04 .25

Accepted: 2016.08.07

Published: 2016.09.20

\begin{abstract}
The aim of the study was to determine the effect of weather components (air temperature, precipitation) on the growth, yield and the length of the growing season of sweet corn cultivated in eastern Poland. The results come from a field experiment conducted in 2006-2011. Weather conditions in the successive years of the study significantly modified the yield of ears, weight and number of formatted ears, high of plants and the length of the growing season of sweet corn. Good yielding of sweet corn favoured years with moderate air temperatures in July and uniform distribution of precipitation during the growing season. The highest yield of ears was found in 2011 , the lowest in the very difficult in terms of weather 2006. The shortest growing season was characterized corn grown in the years 2006 and 2010 with the high air temperatures in July and August, the longest in the years 2009 and 2011, in which the temperatures in the period June-August were the lowest of all the years of research. Irrespective of the year of study, $\mathrm{cv}$ 'Sheba $\mathrm{F}_{1}$ ' was formatted eras with higher weight than $\mathrm{cv}$ 'Sweet Nugget $\mathrm{F}_{1}$ '.
\end{abstract}

Keywords: air temperature, precipitation, yield, growing season, Zea mays L. var saccharata,

\section{INTRODUCTION}

Sweet corn is a valuable crop plant with many applications in human nutrition. It is rich in protein and many sugars, vitamins and microelements. The total output of sweet corn has increased by $60 \%$ worldwide in the last 25 years [Williams et al. 2006]. The plant's popularity is increasing in Poland, too, and the area under sweet corn exceeded 5 th ha in 2010 [Breś 2010]. Soil and climatic conditions of Poland favour the cultivation of sweet corn and production profitability is very high [Wierzbicka 1998, Rosa 2014]. The climate of most Poland is conducive to the cultivation of this crop though the most favourable conditions are in the south and south-western regions. Sweet corn is planted across a range of dates depending on the region [Waligóra and Kruczek 2003]

The growth and yield potential of sweet corn are predominantly affected by air tem- perature and precipitation during the growing season [Waligóra1998, Stone et al. 1999, Genc et al. 2013]. For quick and uniform emergence is required temperature above $10^{\circ} \mathrm{C}$ and moderate soil moisture. Low temperatures and high humidity causes delaying emergence and their thinning. A high soil moisture content irrespective of temperature causes rotting of germinating seeds. The optimum temperature from germination to flowering ranges from $21-27^{\circ} \mathrm{C}$. In the flowering period very damaging is temperature above $30^{\circ} \mathrm{C}$, with simultaneous low humidity. The demand for water depends on the development phase of corn; the lowest is in the early stages (approx. $100 \mathrm{~mm}$ ), the largest $(150-200 \mathrm{~mm})$ in the period of flowering and ears formation. During the ears ripening water demand falls again and amounted to 50-100 mm [Waligóra 1994, Niedziółka et al. 2004, Szulc and Kruczek 2008]. 
The aim of the study was to determine the effect of weather conditions of eastern Poland on the yield, plant growth and length of the growing season of 'Sweet Nugget $F_{1}$ ' and 'Sheba $\mathrm{F}_{1}$ ' sweet corn.

\section{MATERIAL AND METHODS}

The experiment was carried out in the years 2006-2011 at the Experimental Farm in Zawady, $25 \mathrm{~km}$ east of Siedlce $\left(52^{\circ} 03^{\prime} \mathrm{N}, 22^{\circ} 33^{\prime} \mathrm{E}\right)$. According to the international system of FAO classification, the soil was Luvisol [WRB FAO 2015]. The soil organic matter content averaged $1.5 \%$, the humus layer reaching the depth of 30-40 cm. Over the years of the experiment, nitrogen $\left(\mathrm{NO}_{3}+\right.$ $\mathrm{NH}_{4}$ ) content oscillated between 39 and 84, phosphorus (P) 51 and 92, potassium (K) 80 and 105 , magnesium $(\mathrm{Mg}) 28$ and 48, calcium $(\mathrm{Ca}) 235$ and $320 \mathrm{mg} \cdot \mathrm{dm}^{-3}$ of soil, whereas $\mathrm{pH}$ in $\mathrm{H}_{2} \mathrm{O}$ from 5.6 to 6.1 . The experiment was established as a randomized block design with three replicates.

The field experiment was set up after winter triticale. Ploughing was carried out in autumn, in the years preceding cultivation of corn. At the same time, farmyard manure at the rate of $30 \mathrm{t} \cdot \mathrm{ha}^{-1}$ was incorporated. In spring, two weeks before sowing the seeds, tillage was carried out, and mineral fertilizers were applied at the following rates: 60 $\mathrm{kg} \mathrm{N}$ (urea), $50 \mathrm{~kg} \mathrm{P}_{2} \mathrm{O}_{5}$ (superphosphate), $180 \mathrm{~kg}$ $\mathrm{K}_{2} \mathrm{O}(60 \%$ potassium chloride) per 1 ha.

Two early extra-sweet corn cultivars were examined: Sweet Nugget $F_{1}$ (Agri-Saaten) and Sheba $F_{1}$ (Seminis Vegetable Seeds). Seeds of sweet corn were sown in the years 2006-2011 between 11 and 24 May, at the between- and within-row spacing of $65 \times 25 \mathrm{~cm}$. When sweet corn plants were $20 \mathrm{~cm}$ high, top dressing of $60 \mathrm{~kg} \mathrm{~N} \cdot \mathrm{ha}^{-1}$ (ammonium nitrate) was applied. Other cultivation practices followed the generally established rules of sweet corn agrotechnology.

The ears were harvested at the stage of milk maturity of kernels, which was at the end of August or the beginning of September. The whole plot area for harvest was $16 \mathrm{~m}^{2}$. During the harvest the following variables were determined:

- total and marketable leafless ear yield $\left(\mathrm{t} \cdot \mathrm{ha}^{-1}\right)$ according to the norm PN-R-75377:1996,

- number of ears per plant and per hectare,

- mean mass of marketable ears (g),

- ear fulfillment.
Ear fulfillment was assigned a value of 1 to 9 , depending on the length of the unfilled kernels at the ear tip. Value 1 indicated that over $40 \mathrm{~mm}$ of the tip was not filled, $2=35$ to $40 \mathrm{~mm}$ of the tip was not filled, $3=30$ to $34 \mathrm{~mm}$ of the tip was not filled, $4=25$ to $29 \mathrm{~mm}$ of the tip was not filled; $5=20$ to $24 \mathrm{~mm}$ of the tip was not filled; $6=15$ to $19 \mathrm{~mm}$ of the tip was not filled; $7=10$ to 14 $\mathrm{mm}$ of the tip was not filled; $8=5$ to $9 \mathrm{~mm}$ of the tip was not filled; and $9=5 \mathrm{~mm}$ or less of the tip was not filled.

In the each year of the study during the sweet corn growing climate data was collected: the average monthly air temperature and the sum of monthly precipitation (Table 1). They come from automatic meteorological station (LB-741) located in the Experimental Farm in Zawady. Precipitation measured by rain gauge RG 50 (with heater) and recorded every hour. To measure the air temperature used the 6-channel thermometer LB-711. To the total evaluation of pluvio-thermal conditions during the growing season was calculated hydrothermal coefficient by Selyaninov ( $k$ ) according to the methodology applied by Skowera and Puła [2004]:

$$
k=\frac{\mathrm{P}}{\sum \mathrm{t} \cdot 0,1}
$$

where: $P$ - total monthly precipitation $(\mathrm{mm})$,

$\sum t$ - total monthly air temperatures $>0^{\circ} \mathrm{C}$ (Table 2).

The results of the experiment were statistically analysed by ANOVA at $\mathrm{F} \leq 0.05$ following the mathematical model for randomized block design. Significance of differences was determined by the Tukey test at the significance level of $\mathrm{P} \leq$ 0.05 [Winer et al. 1991]. All the calculations were performed in Statistica ${ }^{\circledR}$ 12.0.

\section{RESULTS AND DISCUSSION}

During the growing season of sweet corn average air temperatures were higher than longterm value by $0.4-2.2^{\circ} \mathrm{C}$ (Table 1 ). The warmest growing season were characterized the years 2006 and 2010, with a particularly hot July, and in 2010 also with the hot August. The lowest air temperature was recorded in 2009. In terms of humidity the worst was 2006, in which from May to July have been very large deficit of precipitation, however in August fell until $227.6 \mathrm{~mm}$ of rain, which represented $80 \%$ of precipitation during 
Table 1. Mean air temperature and the sum of rainfall at the Weather Station in Zawady during the seasons 2006-2011 in comparison to the 40-year average ( + or - )

\begin{tabular}{|c|c|c|c|c|c|}
\hline \multirow{2}{*}{ Years } & \multicolumn{4}{|c|}{ Months } & \multirow{2}{*}{$\begin{array}{l}\text { Growing season of } \\
\text { sweet corn }\end{array}$} \\
\hline & $\mathrm{V}$ & $\mathrm{VI}$ & VII & VIII & \\
\hline \multicolumn{6}{|c|}{ Air temperatures $\left({ }^{\circ} \mathrm{C}\right)$} \\
\hline 2006 & $\begin{array}{c}13.6 \\
(+0.4)\end{array}$ & $\begin{array}{c}17.2 \\
(+1.0)\end{array}$ & $\begin{array}{c}22.3 \\
(+4.7)\end{array}$ & $\begin{array}{c}18.0 \\
(+1.1)\end{array}$ & $\begin{array}{c}17.8 \\
(+1.8)\end{array}$ \\
\hline 2007 & $\begin{array}{c}14.6 \\
(+1.4)\end{array}$ & $\begin{array}{c}18.2 \\
(+2.0)\end{array}$ & $\begin{array}{c}18.9 \\
(+1.3)\end{array}$ & $\begin{array}{c}18.9 \\
(+2.0)\end{array}$ & $\begin{array}{c}17.7 \\
(+1.7)\end{array}$ \\
\hline 2008 & $\begin{array}{l}12.7 \\
(-0.5) \\
\end{array}$ & $\begin{array}{c}17.2 \\
(+1.0)\end{array}$ & $\begin{array}{c}18.4 \\
(+0.8) \\
\end{array}$ & $\begin{array}{c}18.6 \\
(+1.7)\end{array}$ & $\begin{array}{c}16.7 \\
(+0.7) \\
\end{array}$ \\
\hline 2009 & $\begin{array}{c}12.9 \\
(-0.3) \\
\end{array}$ & $\begin{array}{c}15.7 \\
(-0.5) \\
\end{array}$ & $\begin{array}{c}19.4 \\
(+1.8) \\
\end{array}$ & $\begin{array}{c}17.7 \\
(+0.8) \\
\end{array}$ & $\begin{array}{c}16.4 \\
(+0.4)\end{array}$ \\
\hline 2010 & $\begin{array}{c}14.0 \\
(+0.8)\end{array}$ & $\begin{array}{c}17.4 \\
(+1.2) \\
\end{array}$ & $\begin{array}{c}21.6 \\
(+4.0)\end{array}$ & $\begin{array}{c}19.8 \\
(+2.9) \\
\end{array}$ & $\begin{array}{c}18.2 \\
(+2.2)\end{array}$ \\
\hline 2011 & $\begin{array}{c}13.5 \\
(+0.3)\end{array}$ & $\begin{array}{c}18.1 \\
(+1.8)\end{array}$ & $\begin{array}{c}18.3 \\
(+0.7)\end{array}$ & $\begin{array}{c}18.0 \\
(+1.1)\end{array}$ & $\begin{array}{c}17.0 \\
(+1.0)\end{array}$ \\
\hline Mean (2006-2011) & $\begin{array}{c}13.5 \\
(+0.3) \\
\end{array}$ & $\begin{array}{c}17.3 \\
(+1.1) \\
\end{array}$ & $\begin{array}{c}19.8 \\
(+2.2)\end{array}$ & $\begin{array}{c}18.5 \\
(+1.6)\end{array}$ & $\begin{array}{c}17.3 \\
(+1.3)\end{array}$ \\
\hline Mean (1951-1990) & 13.2 & 16.2 & 17.6 & 16.9 & 16.0 \\
\hline \multicolumn{6}{|c|}{ Precipitation (mm) } \\
\hline 2006 & $\begin{array}{c}39.6 \\
(-14.7) \\
\end{array}$ & $\begin{array}{c}24.0 \\
(-45.3) \\
\end{array}$ & $\begin{array}{c}16.2 \\
(-54.4)\end{array}$ & $\begin{array}{c}227.6 \\
(+167.8) \\
\end{array}$ & $\begin{array}{c}307.4 \\
(+53.4) \\
\end{array}$ \\
\hline 2007 & $\begin{array}{c}59.1 \\
(+4.8) \\
\end{array}$ & $\begin{array}{c}59.0 \\
(-10.3) \\
\end{array}$ & $\begin{array}{l}70.2 \\
(-0.4)\end{array}$ & $\begin{array}{c}31.1 \\
(-28.7) \\
\end{array}$ & $\begin{array}{l}219.4 \\
(-34.6)\end{array}$ \\
\hline 2008 & $\begin{array}{c}85.6 \\
(+31.3)\end{array}$ & $\begin{array}{c}49.0 \\
(-20.3)\end{array}$ & $\begin{array}{l}69.8 \\
(-0.8) \\
\end{array}$ & $\begin{array}{c}75.4 \\
(+15.6) \\
\end{array}$ & $\begin{array}{c}279.8 \\
(+25.8)\end{array}$ \\
\hline 2009 & $\begin{array}{c}68.9 \\
(+14.9) \\
\end{array}$ & $\begin{array}{c}145.2 \\
(+75.9) \\
\end{array}$ & $\begin{array}{c}26.4 \\
(-44.2) \\
\end{array}$ & $\begin{array}{c}80.9 \\
(+21.1) \\
\end{array}$ & $\begin{array}{c}321.4 \\
(+67.4) \\
\end{array}$ \\
\hline 2010 & $\begin{array}{c}93.2 \\
(+38.9) \\
\end{array}$ & $\begin{array}{l}62.6 \\
(-6.7) \\
\end{array}$ & $\begin{array}{c}77.0 \\
(+6.4) \\
\end{array}$ & $\begin{array}{c}106.3 \\
(+46.5) \\
\end{array}$ & $\begin{array}{c}339.1 \\
(+85.1) \\
\end{array}$ \\
\hline 2011 & $\begin{array}{c}36.1 \\
(-18.2) \\
\end{array}$ & $\begin{array}{c}39.1 \\
(-30.2) \\
\end{array}$ & $\begin{array}{c}120.2 \\
(+49.6) \\
\end{array}$ & $\begin{array}{c}18.6 \\
(-41.2) \\
\end{array}$ & $\begin{array}{l}214.0 \\
(-40.0)\end{array}$ \\
\hline Mean (2006-2011) & $\begin{array}{c}63.8 \\
(+9.5) \\
\end{array}$ & $\begin{array}{l}63.2 \\
(-6.1)\end{array}$ & $\begin{array}{l}63.3 \\
(-7.3) \\
\end{array}$ & $\begin{array}{c}90.0 \\
(+30.2) \\
\end{array}$ & $\begin{array}{c}280.3 \\
(+26.3) \\
\end{array}$ \\
\hline Mean (1951-1990) & 54.3 & 69.3 & 70.6 & 59.8 & 254.0 \\
\hline
\end{tabular}

Table 2. Hydrothermal coefficient $k$ by Selyaninov

\begin{tabular}{|c|c|c|c|c|c|}
\hline \multirow{2}{*}{ Years } & \multicolumn{4}{|c|}{ Months } & \multirow{2}{*}{$\begin{array}{l}\text { Vegetation period of } \\
\text { sweet corn }\end{array}$} \\
\hline & V & $\mathrm{VI}$ & VII & VIII & \\
\hline 2006 & $0.97(\mathrm{sd})^{*}$ & $0.47(\mathrm{~d})$ & $0.24(\mathrm{~d})$ & $4.21(\mathrm{hh})$ & $1.47(\mathrm{gh})$ \\
\hline 2007 & 1.35 (gh) & $1.08(\mathrm{gh})$ & $1.24(\mathrm{gh})$ & $0.55(\mathrm{sd})$ & 1.06 (gh) \\
\hline 2008 & $2.24(\mathrm{hh})$ & 0.95 (sd) & $1.26(\mathrm{gh})$ & 1.35 (gh) & 1.45 (gh) \\
\hline 2009 & 1.78 (gh) & 3.08 (hh) & 0.45 (d) & $1.53(\mathrm{gh})$ & $1.71(\mathrm{gh})$ \\
\hline 2010 & $2.21(\mathrm{hh})$ & $1.13(\mathrm{gh})$ & $1.19(\mathrm{gh})$ & 1.79 (gh) & 1.58 (gh) \\
\hline 2011 & 0.89 (sd) & $0.72(\mathrm{sd})$ & $2.19(\mathrm{hh})$ & $0.34(d)$ & 1.04 (gh) \\
\hline
\end{tabular}

* Value $k$ - period: $<0.50$ - drought (d), 0.51-1.00 - semi-drought (sd), 1.01-2.00 - good humidity (gh), $>2.01$ - high humidity (hh) [Waligóra et al. 2013]

the whole growing season of sweet corn (Table 1). Such a distribution of precipitation in combination with the warm weather had a negative effect on the growth and yield of sweet corn. Deficit the amount of precipitation compared to the years 1951-1990 was recorded also in 2007 and 2011, but not always it had a negative effect on the yield of sweet corn ears. Kovaćecić and Culjat [1993] and Stone et al. [1999] report that the air temperature is a factor in the greater degree influencing the growth, development and yield of corn than the amount of precipitation. In turn, Michalski [1997] considers that the cause of weaker yielding of corn is insufficient of precipitation. Whereas Sulewska [2004] states that the crop yields of sweet corn depends not so much on the amount 
as on the distribution of precipitation in the growing season. This author, but also Waligóra et al. [2010] believe that in Polish climatic conditions on the yields of corn in the higher degree decide the total precipitation in June and July.

Diversified course of the weather conditions during the years of the study was reflected in the level of yields of sweet corn (Tables 3 and 4). Significantly the highest yield of total and marketable ears were harvested in 2011. An average for cultivars amounted to 20.18 and $18.30 \mathrm{t} \cdot \mathrm{ha}^{-1}$ (Table 3). Also marketable yield expressed as the number of ears harvested from 1 ha was the largest in 2011 and amounted to 68681 (Table 4). It was over $25 \%$ more than the average of all the years of research. In 2011, in May and June was recorded a deficit of precipitation compared to the long-term average, but it did not affect nega- tively on emergence and initial growth of sweet corn plants. However, in July the total precipitation amounted to $120.2 \mathrm{~mm}$ and combined with not very high air temperature influenced very favourably on the flowering of corn and ears formation. The average number of marketable ears per plant amounted to 1.1 and was also the largest of all the years of research(Table 4). It is consistent with the research of Waligóra [1994], Szulc and Kruczek [2008] and Waligóra et al. [2010]. The authors stated that the good flowering and ears formation favour higher soil moisture, combined with moderate air temperatures. The lowest yield of sweet corn was achieved in 2006. Irrespective of cultivar the total and marketable yields of ear amounted to 9.05 and $7.77 \mathrm{t} \cdot \mathrm{ha}^{-1}$ and were from 28 to $57 \%$ lower compared to the yields harvested in the remaining years of the study. The number

Table 3. Yielding of sweet corn $\left(\mathrm{t} \cdot \mathrm{ha}^{-1}\right)$

\begin{tabular}{|c|c|c|c|c|c|c|}
\hline \multirow{3}{*}{ Years } & \multicolumn{3}{|c|}{ Total leafless ear yield } & \multicolumn{3}{|c|}{ Marketable leafless ear yield } \\
\hline & \multicolumn{2}{|c|}{ Cultivar } & \multirow{2}{*}{ Mean } & \multicolumn{2}{|c|}{ Cultivar } & \multirow{2}{*}{ Mean } \\
\hline & Sweet Nugget $F_{1}$ & Sheba $F_{1}$ & & Sweet Nugget $F_{1}$ & Sheba $\mathrm{F}_{1}$ & \\
\hline 2006 & $9.33 a^{*}$ & $8.77 \mathrm{a}$ & $9.05 \mathrm{a}$ & $7.47 \mathrm{a}$ & $8.07 \mathrm{a}$ & $7.77 \mathrm{a}$ \\
\hline 2007 & $13.80 \mathrm{~b}$ & $15.47 \mathrm{~b}$ & $14.63 \mathrm{~b}$ & $12.11 \mathrm{a}$ & $12.33 \mathrm{a}$ & $12.22 \mathrm{bc}$ \\
\hline 2008 & $18.77 \mathrm{~d}$ & $16.67 \mathrm{~b}$ & $17.72 \mathrm{~d}$ & $16.70 \mathrm{a}$ & $14.53 \mathrm{a}$ & $15.62 \mathrm{de}$ \\
\hline 2009 & $17.46 \mathrm{~d}$ & $16.67 \mathrm{~b}$ & $17.07 \mathrm{~cd}$ & $14.59 \mathrm{a}$ & $15.49 \mathrm{a}$ & $15.04 \mathrm{~cd}$ \\
\hline 2010 & $15.32 \mathrm{c}$ & $15.38 b$ & $15.35 \mathrm{bc}$ & $11.71 \mathrm{a}$ & $9.94 \mathrm{a}$ & $10.83 b$ \\
\hline 2011 & $20.54 \mathrm{e}$ & $19.82 \mathrm{c}$ & 20.18 e & $18.79 \mathrm{a}$ & $17.81 \mathrm{a}$ & $18.30 \mathrm{e}$ \\
\hline Mean & $15.87 A^{* *}$ & $15.46 \mathrm{~A}$ & 15.67 & $13.56 \mathrm{~A}$ & $13.03 \mathrm{~A}$ & 13.30 \\
\hline $\begin{array}{l}\text { Standard } \\
\text { deviation }\end{array}$ & 3.93 & 3.51 & 3.66 & 4.17 & 3.58 & 3.66 \\
\hline $\begin{array}{c}\text { Variability } \\
\text { coefficient }\end{array}$ & 24.8 & 22.7 & 23.4 & 30.7 & 27.5 & 27.5 \\
\hline
\end{tabular}

* Values within columns followed by the same lowercase letters are not significantly different at $\mathrm{P} \leq 0.05$

** Values within rows followed by the same uppercase letters are not significantly different at $\mathrm{P} \leq 0.05$

Table 4. Number of sweet corn ears

\begin{tabular}{|c|c|c|c|c|c|c|}
\hline \multirow{2}{*}{ Years } & \multicolumn{3}{|c|}{ Number of ears per plant } & \multicolumn{3}{c|}{ Number of ears per 1 hectare } \\
\cline { 2 - 3 } & \multicolumn{2}{|c|}{ Cultivar } & \multirow{2}{*}{ Mean } & \multicolumn{2}{c|}{ Cultivar } & \multirow{2}{*}{ Mean } \\
\cline { 2 - 3 } \cline { 5 - 7 } & Sweet Nugget $\mathrm{F}_{1}$ & Sheba $\mathrm{F}_{1}$ & & Sweet Nugget $\mathrm{F}_{1}$ & Sheba $\mathrm{F}_{1}$ & \\
\hline 2006 & $0.8 \mathrm{a}^{*}$ & $0.8 \mathrm{a}$ & $0.8 \mathrm{a}$ & $41380 \mathrm{a}$ & $41533 \mathrm{a}$ & $41457 \mathrm{a}$ \\
\hline 2007 & $0.9 \mathrm{a}$ & $1.0 \mathrm{a}$ & $1.0 \mathrm{bc}$ & $53708 \mathrm{bc}$ & $56542 \mathrm{bc}$ & $55125 \mathrm{ab}$ \\
\hline 2008 & $1.1 \mathrm{a}$ & $0.9 \mathrm{a}$ & $1.0 \mathrm{bc}$ & $61767 \mathrm{c}$ & $52117 \mathrm{~b}$ & $56942 \mathrm{ab}$ \\
\hline 2009 & $0.9 \mathrm{a}$ & $0.9 \mathrm{a}$ & $0.9 \mathrm{ab}$ & $55788 \mathrm{c}$ & $57934 \mathrm{bc}$ & $56861 \mathrm{ab}$ \\
\hline 2010 & $0.7 \mathrm{a}$ & $0.8 \mathrm{a}$ & $0.8 \mathrm{a}$ & $47022 \mathrm{ab}$ & $51929 \mathrm{~b}$ & $49476 \mathrm{a}$ \\
\hline 2011 & $1.1 \mathrm{a}$ & $1.0 \mathrm{a}$ & $1.1 \mathrm{c}$ & $75134 \mathrm{~d}$ & $62228 \mathrm{c}$ & $68681 \mathrm{~b}$ \\
\hline Mean & $0.9 \mathrm{~A}^{* *}$ & $0.9 \mathrm{~A}$ & 0.9 & $55800 \mathrm{~A}$ & $53714 \mathrm{~A}$ & 54757 \\
\hline $\begin{array}{c}\text { Standard } \\
\text { deviation }\end{array}$ & 0.2 & 0.2 & 0.1 & 12953 & 20722 & 9362 \\
\hline $\begin{array}{l}\text { Variability } \\
\text { coefficient }\end{array}$ & 22.2 & 22.2 & 11.1 & 23.2 & 20.0 & 17.1 \\
\hline
\end{tabular}

* Values within columns followed by the same lowercase letters are not significantly different at $\mathrm{P} \leq 0.05$

** Values within rows followed by the same uppercase letters are not significantly different at $\mathrm{P} \leq 0.05$ 
of marketable ears from hectare amounted to 41457 and was lower by $16-40 \%$ than in the years 2007-2011. It was a consequence of the very difficult pluvio-thermal conditions in 2006. The coefficient $\mathrm{k}$ for June and July amounted to only 0.47 and 0.24 (Table 2). According to Michałojć et al. [1996] and Waligóra and Kruczek [2003] the critical periods in terms of the demand of corn on water are the seeds germination and initial growth of plants (May-June) as well as plants flowering (July).In addition, hot and humid weather in August $(\mathrm{k}=4.21)$ caused that the panicles and already formatted ears have been attacked by Corn smut. The number of infected ears reached $20 \%$. Also, Waligóra et al. [2008] and Ptaszyńska and Sulewska [2007] was found that warm and humid weather in 2006 was the cause of infection by Ustilago maydis from 1.7 to $27.3 \%$ plants of different cultivars of sweet corn. In the author's own studies, also in 2010 the high air temperature and a large amount of precipitation in July and August favoured infection of sweet corn by U. maydis, which also affected on the yields level.

The highest (90.5\%) and the lowest (70.2\%) share of marketable yield in the total yield of ears was characterized corn cultivated in 2011 and 2010, respectively (Figure 1).

The weight of marketable ears harvested in the years 2008-2011 was similar (Table 5). Irrespective of the sweet corn cultivars was ranged from 254.9 to $276.7 \mathrm{~g}$. The marketable ears with the lowest weight $(189.9 \mathrm{~g})$ was harvested in 2006, the least favourable for sweet corn growth. The ears of 'Sheba $\mathrm{F}_{1}$ ' were characterized by significantly higher weight than ears of 'Sweet Nugget $\mathrm{F}_{1}$ '. The average ear fulfillment according to the 9-degree scale amounted to 8.0. Irrespective of the cultivar the best fulfillment ears (8.6-8.9)

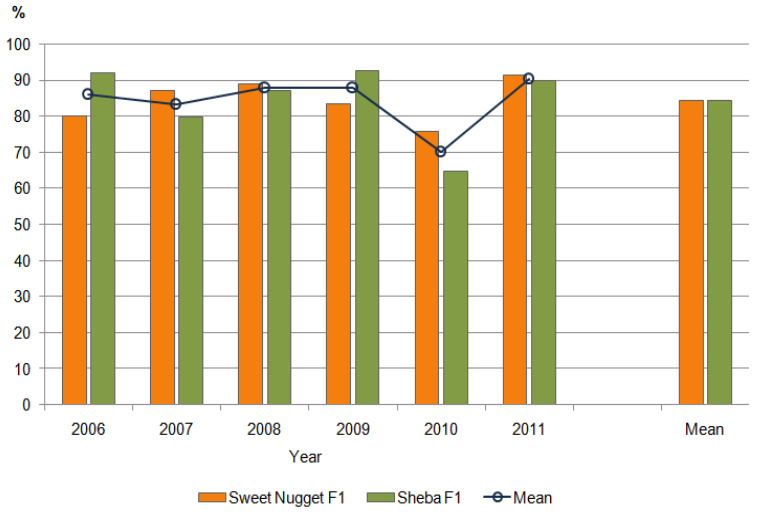

Figure 1. Share of marketable yield of sweet corn ears in total yield harvested in the years 2009, 2010 and 2011, the least in the years 2006 and 2007 (6.8-7.3).

The length of the growing season of sweet corn amounted an average 101 days. This feature was strongly modified by weather conditions during the years of the study (Figure 2). Irrespective of the cultivar the longest growing season had corn cultivated in the years 2009 and 2011, respectively 115 and 113.5 days. In the period from June to August these years were characterized by lower than in the remaining years air temperatures, and 2009 also large amount of precipitation. The shortest growing season (91.5 days) was characterized sweet corn in the years 2006 and 2010, in which in the summer month was noted high air temperatures, and 2006 was also characterized by the large deficit of precipitation in June and July. Such conditions significantly accelerated the growth and yield of corn. Waligóra and Kruczek [2003], Waligóra et al. [2010] and Khan et al. [2011] stressed that the cause of elongating of sweet corn growing season are among others low spring temperatures, which extends the germination of seeds, and low temperatures in July affecting the generative growth of plants. In turn, Martin et al. [1976] and Waligóra et al. [2010] was found that warm and dry weather during sweet corn flower in accelerates of pollen shattering, which shortens the growing season.

The highest growth characterized corn plants in the years 2008 and $2011(173.4 \mathrm{~cm}$ and 181.0 $\mathrm{cm}$ high), the weakest in $2006(99.4 \mathrm{~cm})$. It was noted the relationship that the higher air temperatures were in June and July, the corn plants were lower. However, it was not found significant differences in the plants high between investigated cultivars of sweet corn (Figure 3).

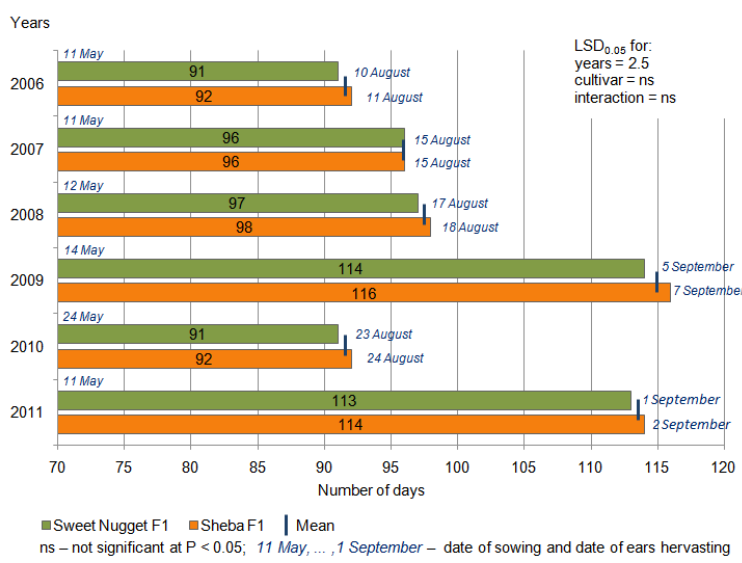

Figure 2. Length of growing season of sweet corn 


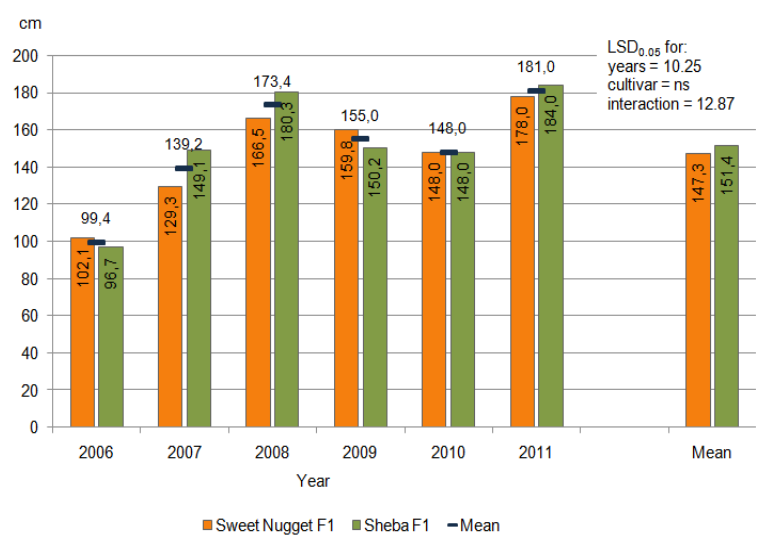

On the basis of calculated correlation coefficients it was found significantly negative correlation between the height of atmospheric temperatures in July and the ears yield, the number of ears per 1 plant and per 1 hectare. It was also found significantly negative influence the level of precipitation in August on the total yield of ears and the number of ears per 1 plant and per 1 hectare (Table 6).

Figure 3. Height of sweet corn plants in 2006-2011

Table 5. Mass of marketable sweet corn ear and ear fulfillment with kernels

\begin{tabular}{|c|c|c|c|c|c|c|}
\hline \multirow{3}{*}{ Years } & \multicolumn{3}{|c|}{ Mass of marketable ear (g) } & \multicolumn{3}{|c|}{ Ear fulfillment (on a 1 to 9 scale) } \\
\hline & \multicolumn{2}{|c|}{ Cultivar } & \multirow{2}{*}{ Mean } & \multicolumn{2}{|c|}{ Cultivar } & \multirow{2}{*}{ Mean } \\
\hline & Sweet Nugget $F_{1}$ & Sheba $F_{1}$ & & Sweet Nugget $F_{1}$ & Sheba $F_{1}$ & \\
\hline 2006 & $183.1 a^{*}$ & 196.6 a & 189.9 a & $6.6 \mathrm{a}$ & $6.9 \mathrm{a}$ & $6.8 \mathrm{a}$ \\
\hline 2007 & $218.4 \mathrm{bc}$ & $215.8 \mathrm{a}$ & $217.1 \mathrm{ab}$ & $7.4 \mathrm{a}$ & $7.2 \mathrm{a}$ & $7.3 \mathrm{a}$ \\
\hline 2008 & $264.1 \mathrm{~d}$ & 266.7 b & $265.4 \mathrm{c}$ & $8.6 \mathrm{a}$ & $8.5 \mathrm{a}$ & $8.6 \mathrm{~b}$ \\
\hline 2009 & $261.4 \mathrm{~d}$ & $267.9 \mathrm{~b}$ & $264.7 \mathrm{c}$ & $8.8 \mathrm{a}$ & $8.7 \mathrm{a}$ & $8.8 \mathrm{~b}$ \\
\hline 2010 & $242.8 \mathrm{~cd}$ & 266.9 b & 254.9 bc & $9.0 \mathrm{a}$ & $8.7 \mathrm{a}$ & $8.9 \mathrm{~b}$ \\
\hline 2011 & $249.5 d$ & $303.9 c$ & $276.7 \mathrm{c}$ & $8.3 \mathrm{a}$ & $7.7 \mathrm{a}$ & $8.0 \mathrm{ab}$ \\
\hline Mean & $236.6 A^{* *}$ & $253.0 \mathrm{~B}$ & 244.8 & $8.1 \mathrm{~A}$ & $8.0 \mathrm{~A}$ & 8.0 \\
\hline $\begin{array}{l}\text { Standard } \\
\text { deviation }\end{array}$ & 32.7 & 41.0 & 34.8 & 1.1 & 0.9 & 0.8 \\
\hline $\begin{array}{l}\text { Variability } \\
\text { coefficient }\end{array}$ & 13.8 & 16.2 & 14.2 & 13.6 & 11.3 & 10.0 \\
\hline
\end{tabular}

* Values within columns followed by the same lowercase letters are not significantly different at $\mathrm{P} \leq 0.05$

** Values within rows followed by the same uppercase letters are not significantly different at $\mathrm{P} \leq 0.05$

Table 6. Coefficient of correlation between mean air temperature and sum of precipitation, and length of the growing period, yields and height of sweet corn plants

\begin{tabular}{|c|c|c|c|c|c|c|c|c|}
\hline Month & $\begin{array}{c}\text { Length of } \\
\text { growing } \\
\text { season }\end{array}$ & Total ear yield & $\begin{array}{c}\text { Marketable } \\
\text { ear yield }\end{array}$ & $\begin{array}{c}\text { Number of } \\
\text { ears per plant }\end{array}$ & $\begin{array}{c}\text { Number of } \\
\text { ears per 1 } \\
\text { hectare }\end{array}$ & $\begin{array}{c}\text { Mass of } \\
\text { marketable } \\
\text { ear }\end{array}$ & $\begin{array}{c}\text { Ear fulfillment } \\
\text { plants }\end{array}$ \\
\hline \multicolumn{7}{|l|}{ Mean air temperature } \\
\hline V V & -0.448 & -0.336 & -0.444 & -0.094 & -0.208 & -0.501 & -0.470 & -0.390 \\
\hline VI & -0.345 & +0.050 & +0.019 & +0.441 & +0.214 & -0.176 & -0.454 & +0.067 \\
\hline VII & -0.610 & $-0.816^{*}$ & $-0.889^{*}$ & $-0.929^{*}$ & $-0.877^{*}$ & -0.617 & -0.260 & -0.795 \\
\hline VIII & -0.663 & -0.050 & -0.310 & -0.277 & -0.243 & -0.002 & 0.273 & +0.015 \\
\hline Sum of precipitation & & & & & & & +0.753 & +0.273 \\
\hline V V & -0.302 & +0.185 & -0.029 & -0.306 & -0.154 & +0.359 & +0.753 \\
\hline VI & +0.570 & +0.299 & +0.264 & -0.104 & +0.171 & +0.393 & +0.581 & +0.225 \\
\hline VII & +0.226 & +0.727 & +0.639 & +0.704 & 0.756 & +0.588 & +0.237 & +0.729 \\
\hline VIII & -0.534 & $-0.861^{*}$ & -0.809 & $-0.816^{*}$ & $-0.882^{*}$ & -0.672 & -0.388 & -0.798 \\
\hline
\end{tabular}

* significant at $\mathrm{P}<0.05$ 


\section{CONCLUSIONS}

1. Weather conditions of eastern Poland are favourable for sweet corn cultivation, however yielding effects in the successive years are modified by the distribution of air temperature and precipitation.

2. In the cooler years with a more uniform distribution of precipitation, yields of ear were higher and growing season was longer. The lowest yields of ear and the shortest growing seasons of sweet corn was recorded in the years with high temperatures in July and August.

3 . The highest yield of ears was harvested in 2011, the lowest in 2006.

4. Irrespective of the year of study, cv 'Sheba $\mathrm{F}_{1}$ ' was formatted eras with higher weight than $\mathrm{cv}$ 'Sweet Nugget $F_{1}$ '.

5. Calculated correlation coefficients indicate that the highest influence on the sweet corn yield had air temperatures in July and amount of precipitation in August.

\section{Acknowledgements}

The research was supported by the Polish Ministry of Science and Higher Education as part of the statutory activities of the Department of Vegetable Crops, Siedlce University of Natural Sciences and Humanities.

\section{REFERENCES}

1. Bereś P.K. 2010. Harmfulness and effects of chemical control of OstrinianubilalisHbn. on sweet corn (Zea mays var. saccharata) in Rzeszów region in 20062009. Acta Sci. Pol., Agricultura 9, 4, 5-15.

2. Genc L., Inalpulat M., Kizil U., Mirik M., Smith S. E. Mendes M. 2013. Determination of water stress with spectral reflectance on sweet corn (Zea mays L.) using classification tree (CT) analysis. ZemdirbysteAgriculture, 100 (1), 81-90.

3. Khan Z.H., Khalil S.K., Farhatullah, Khan M.Y., Israr M., Basir A. 2011. Selecting optimum planting date for sweet corn in Peshawar, Pakistan. Sarhad J. Agric. 27, 3, 341-347.

4. Kovaćecić V., Culjat M. 1993. Some experiments with corn growing at southern Poland. Fragm. Agron. 3, 75-90.

5. Niedziółka I., Szymanek M., Rybczyński R. 2004. Technologia produkcji kukurydzy cukrowej. Acta Agrophys., Rozprawy i Monografie 114, 8, 83 p.

6. Martin J.H., Leonard W.H., Stamp D.L. 1976. Principles of field crop production. Macmillan, New York.

7. Michalski T. 1997. Wartość pastewna plonów kukurydzy w zależności od sposobów i terminów zbioru. Zesz. Probl. Post. Nauk Roln. 450, 133-162.
8. Michałojć Z., Nurzyński J., Kossowski J. M. 1996. Wpływ nawożenia azotowo-potasowego na plonowanie i skład chemiczny kukurydzy cukrowej. Annal. UMCS, sec. EEE, IV (13), 95-103.

9. Ptaszyńska G., Sulewska H. 2007. Wpływ warunków pogodowych na porażenie kukurydzy grzybem Ustilago Zeae Unger. Prog. Plant Protection / Post. Ochr. Roślin 47, 2, 280-283.

10. Rosa R. 2014. Economic effects of summer catch crops application in sweet corn cultivation. Infrastruktura i Ekologia Terenów Wiejskich, IV/3, 1445-1455.

11. Skowera B., Puła J. 2004. Skrajne warunki pluwiometryczne w okresie wiosennym na obszarze Polski w latach 1971-2000. Acta Agrophys. 3, 1, 171-177.

12. Stone P.J., Sorensen I.B., Jamieson P.D. 1999. Effect of soil temperature on phenology, canopy, development, biomass and yield of maize in a cool-temperate climate. Field Crop Research 63, 169-178.

13. Sulewska H. 2004. Wymagania środowiskowe kukurydzy i możliwości jej uprawy w Polsce. (w:) Technologia produkcji kukurydzy. red. Dubas A., wyd. „Wieś Jutra”, 16-23.

14. Szulc P., Kruczek A. 2008. Wpływ wielkości opadów i temperatury na gromadzenie suchej masy i pobieranie składników mineralnych przez kukurydzę w początkowym okresie rozwoju w zależności od sposobu nawożenia. Acta Agrophys. 11, 3, 753-766.

15. Szulc P., Waligóra H., Skrzypczak W. 2008. Susceptibility of two maize cultivars to diseases and pests depending on nitrogen fertilization and on the method of magnesium application. Nauka Przyr. Technol. 2, 2 \#11.

16. Waligóra H. 1994. Agrotechnika kukurydzy cukrowej. Kukurydza 1 (2).

17. Waligóra H. 1998. Uprawa i wykorzystanie kukurydzy cukrowej. Nowoczesne Rolnictwo 4, 10-11.

18. Waligóra H., Kruczek A. 2003. Wpływ zróżnicowanego nawożenia azotem i nawozami wieloskładnikowymi na plon i jakość surowca kukurydzy cukrowej. Acta Sci. Pol., Agricultura 2(1), 57-65.

19. Waligóra H., Szulc P., Skrzypczak W. 2008. Podatność odmian kukurydzy cukrowej na głownię guzowatą (Ustilago zeae Beckm.). Nauka Przyr. Technol. 2, 3,\#17.

20. Waligóra H., Skrzypczak W., Weber A., Szulc P. 2010. Plonowanie i długość okresu wegetacji kilku odmian kukurydzy cukrowej w zależności od warunków pogodowych. Nauka Przyr. Technol. 4, 1, \#5.

21. Wierzbicka B. 1998. Efektywność ekonomiczna produkcji kukurydzy cukrowej. Zesz. Nauk. AR Kraków 330 (54), 589-591.

22. Winer B.J., Brown D.R., Michels K.M. 1991. Statistical principles in experimental design. McGraw-Hill New York.

23. Williams M.M., Masiunas J.B. 2006. Functional relationships between giant ragweed (Ambrosia trifida) interference and sweet corn yield and ear traits. Weed Sci. 54, 948-953.

24. World Reference Base for Soil Resources 2014 (WRB FAO). 2015. World Soil Resource Reports FAO 106, Rome. 